\title{
Does Real Earnings Management Explain Cost of Debt? Evidence from an Emerging Economy
}

\author{
Nguyen Vinh Khuong ${ }^{1,2^{*}}$, Nguyen Thanh Liem ${ }^{2,3}$ \\ and Bui Thi Ngan Dung ${ }^{1,2}$ \\ ${ }^{1}$ Faculty of Accounting and Auditing, \\ University of Economics and Law, Vietnam \\ ${ }^{2}$ Vietnam National University, Vietnam \\ ${ }^{3}$ Faculty of Banking and Finance, University of Economics and Law, Vietnam
}

\begin{abstract}
This study tested the relationship between real earnings management and debt cost in Vietnam, a developing market. We used the Generalized Method of Moments (GMM) Technique on a sample of 241 listed firms in Vietnam for 7 years from 2010 to 2016, with a total of 1687 observations collected. The regression result showed a positive association between real earnings management and cost of debt. The results of the study revealed that real earnings management is shown through the rising transactions and directly affected financial reports, thereby affecting creditors by affecting their cost of debt. This can be seen as the driving force for listed companies to increase the quality of their financial information. Our study only focussed on earnings manipulation through real earnings management (REM) to affect transaction costs in Vietnam. The research explains the relationship between managerial behavior (real earnings management) and direct influence on creditors' behavior (cost of debt capital). The result would give outside stakeholders an overall view about the usage of REM in Vietnamese listed firms, the reasonable action of investors, financial institutions, banks, etc on the debt market to reduce risk and the signal of warning for regulators and policy-makers.
\end{abstract}

Keywords: real activities earnings management, cost of debt capital

\section{ARTICLE INFO}

\section{Article History:}

Received: 17 February 2021

Accepted: 26 July 2021

Published: 1 December 2021

* Corresponding author: Nguyen Vinh Khuong. E-mail: khuongnv@uel.edu.vn 


\section{INTRODUCTION}

The behavior of earnings management depends on the decisions of a company's board of directors, so on the negative side, this behavior is intended to conceal the financial position of the company. Because these real business activities diverge from optimal business actions, real earnings management also imperils a firm's ambitious position in the long period (Zang, 2012). The Agency Theory (AT) declares that debt adjusting is defined by the appearance of inherent conflicts of benefit and asymmetric information problem between the agent and the principal, leading to an increase in the monitoring costs of debt (Jensen \& Meckling, 1976).

In this study, we investigated the association between real earnings management and the cost of debt in Vietnamese listed companies. Our sample included 241 listed firms and covered the period 2010 to 2016. We used abnormal levels of cash flow from operations (REMCFO), discretionary expenses (REM_DISX) and production costs (REMPROD) variables as proxies for real activities manipulation (Cohen \& Zarowin, 2010; Roychowdhury, 2006). Following Gray, Koh, and Tong (2009) since information on the interest rates charged on bank loans is not available, cost of debt capital was calculated through the firm's interest expense. We used the GMM regression model to test the association between real earnings management and the cost of debt with some control variables for the cost of debt.

Recent studies sought to find evidence of managers prioritizing the use of accrual based earnings management (AEM) or REM in specific contexts. However, investigations concentrated on the impact of AEM more than REM because financial statements can be adjusted through accounting policies. In fact, manipulative accounting results in financial statements through REM can help managers to change the net income by some secure and efficient alternative solution (Roychowdhury, 2006; Zang, 2012). Therefore, the choice of earnings management behaviour has an impact on stakeholders and on sustainable development of firms. In companies using debt, which is the main capital in their capital structure, managers frequently perform to depreciate the cost of debt to accomplish firm aims. So, managers use accounting estimates to manipulate earnings and depicting a good financial position to help them to obtain better debt contracting. A 
recent study has examined the impact of earnings management on cost of debt and has commonly confirmed that discretionary accruals or abnormal accruals as a proxy of AEM have a positive value influence on cost of debt (Bharath, Sunder, \& Sunder, 2008; Francis, LaFond, Olsson, \& Schipper, 2005). However, previous studies focus exclusively on the effect of AEM in the stock market and are primarily conducted in developed countries and effective markets (Aldamen \& Duncan, 2013; Bharath et al., 2008; Gray et al., 2009).

If the investor does not clearly distinguish managerial opportunism from a manager, real earnings management can be mistaken as operational efficiency. For example, curiously huge sales discounts may be deemed as an effective sales promotion strategy; overstock is classified as normal business actions to build a reserve that will be used when an expansion in revenue is needed to reach a profit target. A signal of firm growth, and an abnormal reduction of discretionary expenditures may be mistaken as an efficient cost saving activity. Therefore, we expect a positive correlation between real earnings management and cost of debt. Hence, holding the limitations of their research as a motive, our research enlarged the analysis by concentrating especially on the influence of real earnings management and the cost of debt in emerging markets, with control variables such as firm size, firm leverage, tangible asset.

This study contributes to the literature on the association between real earnings management and the cost of debt in emerging markets such as Vietnam. Currently, there is little research on real earnings management and the cost of debt in Vietnam. The empirical evidence in this study is significant for the Vietnamese stock market and users who use financial reports. The findings of this paper will help in comprehending the behavior of financial institutions in the lending process. Besides, listed firms have to establish suitable strategies to decrease the cost of debt. In this way, the study extends the AT literature (Jensen \& Meckling, 1976), specifically in resolving the problem of the dispute between creditors and users and information intermediaries related to the quality of financial statements.

The results of this study can help authorities in management through understanding the role of real activities earnings management in listed firms. Companies listed on the stock market can provide reliable financial reporting 
quality to help the stock market by being more transparent. Moreover, debt providers are also concerned about accepting interest policies and advances for a company to enhance their reputation. Thus, the research findings can be of interest to managers and financial institutions in emerging markets.

The next section explains the theoretical background and hypothesis development, Section 3 indicates the research methodology and sample selection process and Section 4 presents the findings and the last section summarises and concludes.

\section{THEORETICAL BACKGROUND AND HYPOTHESIS DEVELOPMENT}

There has been an extensive diversity of definitions of earning management. Schipper (1989, p.92) firstly defined earning management as "a purposeful intervention in the external financial reporting process" to "obtain private gain" and "facilitate the neutral operation of the process". Following that bedrock, other definitions were presented differently, which emphasized the ways and goals when managers manipulate earnings (Healy \& Wahlen, 1999; Phillips, Pincus, Rego, \& Wan, 2004; Walker, 2013). Ronen and Yaari, (2008) showed two main activities (real vs. accrual) while researches following Laux and Laux (2009); Gelb and Zarowin (2002); Goldman and Slezak (2006), El Diri (2018) considered the benefits of earning management incentives as conditions that managers abuse to manipulate earnings. In general, earning management is seen as a management's discretion or opportunistic behavior within regulations for reaching desired outcomes and hiding true performance.

Managers can use various types of earnings management activities to improve presentation of earnings in financial statements and mislead stakeholders. Accrual earnings management (AEM) is used through changing accounting policies accepted by GAAP and thereby breaking the way financial statements are presented. Hence, this may also be justified by the nature of the transaction or manipulating the transaction in an inappropriate way of noting. In contradiction, real activities earnings management has gained the attention of researchers since 2005, based on the studies of Graham et al. (2005) and Roychowdhury (2006), focusing 
on real economic decisions, and the normal business activities taking place regularly in corporations. Nevertheless, it is extraordinarily challenging to estimate the actual influence on the future cash flow of a business if managers practice REM rather than AEM due to the fact that outside stakeholders need specialised knowledge to detect and distinguish whether the REM is beneficial or pernicious (Kothari, Mizik, \& Roychowdhury, 2015). There are many different strategies for AEM including smoothing, changing the categorization and other techniques to achieve previously set goals.

The AT says that the relationship between executives and stakeholders is contractual, which is like the principal - agent problem due to the conflicts of interest between the principal (shareholders, banks, debt providers...) and the agent (executives, borrowers), hence causing information asymmetry (Jensen \& Mecking, 1976). Information asymmetry causes managers to include private reasons in decision making or make decisions that are not aligned with shareholders' interest. In more detail, earnings manipulation is practised through the use of accounting policies and derivatives where managers can customise profit information according to individual forecasts. This has a long-term impression on the growth of a company and enhances information asymmetry among stakeholders (Hadani, Goranova, \& Khan, 2011). Therefore, investors need to have a compensation to ensure the quality of information and asymmetric risks called cost of capital or opportunity cost when they decide to contribute capital to those shares in lieu of others in the capital market. When it comes to shareholders and cost of equity, Francis et al. (2005) proposed that investors perceive that managers' incentives through accruals, and indicated the association between discretionary accruals with greater equity beta, which infers a high cost of equity. According to the research of Gray et al. (2009), Balvers (2009) the cost of debts involving interest has a positive association with earnings management. Prevost et al. (2008) accepted that earnings management raises transaction costs through the practice of the margin debt method in the bond market and this result is supported by Francis et al. (2005). Graham et al. (2005) carried out a survey asking managers why they favoured smoothing income and the first positioned response $(88,7 \%)$ was because investors think that when income is stable, the risk is likely to decrease. Most found that it reduces the return investors demand by reducing the cost of capital as income is adjusted. 
Specifically, to REM and cost of debt, we prognosticated that REM increases the cost of debt due to two main reasons. Firstly, REM with real business activities such as production, sales, investment, and finance can distort future cash flow levels. For example, the extending of the credit terms would increase present-period's revenue, but it can post the threat of a bad debt and reduce future cash flow for operations and investments. Secondly, as mentioned before, REM is more difficult to expose than AEM. Outside investors, financial institutions and external monitoring and scrutiny by auditors find it hard to understand precisely due to the fact that it is related to real policies and the lack of information stemming from the nature of a business and whether or not it is efficient. The empirical results of studies in this field show the same correlation between REM and cost of debt. Research by Kim and Sohn (2013) in the US explicates that the more managers act to utilize REM, the higher the cost of capital (including cost of debt and cost of equity). Kim et al. (2018) with international evidence also prove a positive association.

There is no doubt to say that emerging markets are ideal places for managers to manipulate earnings due to weak auditing, lax in enforcement, complicated and controversial regulations (Chen, Chen, Lobo, \& Wang, 2010; Firth, Mo, \& Wong, 2012; Hu, Weng, \& Wang, 2020). Among those techniques of earnings management, REM and AEM seem to be popular than others, which use the same practices of REM and AEM but are under different names to reflect the nature of earnings change. While AEM has a long history and discovered practices, REM would be the best choice because it is fairly invisible from the various other updated techniques hidden in normal operating activities. The complication of REM techniques makes investors require a higher cost of debt to compensate for the higher level of information risks and Vietnam is not an exception. Therefore, our hypothesis regarding the association between REM and cost of debt in Vietnam is as follows.

$\mathbf{H}_{1}$ : The extent of real earnings management is positively associated with the cost of debt in Vietnam. 


\section{DATA AND METHODOLOGY}

\section{Data}

Secondary data from audited financial statements was used in the study to calculate the variables in the research model. To test H1, we estimated a panel data type, dynamic GMM regression was required to control endogenous phenomena using the STATA software. On two stock exchanges in Vietnam, there were 735 listed companies. We excluded listed companies in the financial and insurance sectors because of different accounting systems and business operations. The remaining sample of the study was 620 non-financial listed companies. We continued to filter nonfinancial listed companies with a listing data from 2010 and full audited financial statements and annual reports published during the study period. After filtering the research sample, there were 241 listed non-financial companies for data analysis. The sample covered 241 public companies listed on the HNX and HOSE in the Vietnam stock market for seven years from 2010 to 2016. We excluded financial institutions due to the difference in accounting practices and the uniqueness of industry characteristics, so a total of 1687 observations were collected.

\section{Model}

This research adopted linear dynamic GMM according to Arellano and Bond (1991) to deal with problems including the omitted variable problem, endogenous problem, heterogeneity problem through hysteresis variable. follows:

The regression model is presented in the form of an equation as

$$
\begin{aligned}
C O D_{i, t}= & \mu C O D(-1)_{i, t}+\delta_{1} R E M_{i, t}+\delta_{2} \operatorname{SIZE}_{i, t}+\delta_{3} R O A_{i, t}+\delta_{4} L E V_{i, t}+ \\
& \delta_{5} P P E_{i, t}+\varepsilon_{i, t}
\end{aligned}
$$

where $\mathrm{i}$ corresponds to firm and $\mathrm{t}$ represents time, and $\epsilon_{\mathrm{it}}$ is error. 


\section{Dependent Variable}

Cost of debt (COD) is the variable representing the cost of debt, which is calculated by the interest expense on the financial statements divided by the total liability (Pittman \& Fortin, 2004; Francis et al., 2005; Lim, 2011; Lorca, Sánchez-Ballesta, \& García-Meca, 2011; Karjalainen, 2011).

\section{Independent Variable}

Based on Roychowdhury (2006), the research applied three metrics to analyse the level of real earnings management, specifically the abnormal levels of cash flow from operations $\left(R E M_{-} C F O_{i, t}\right)$, production costs $\left(R E M_{-}\right.$ $\left.P R O D_{i, t}\right)$ and discretionary expenses (REM_DISX $\left.X_{i, 1}\right)$.

$$
\frac{C F O_{i, t}}{A_{i, t-1}}=\beta_{1} \frac{1}{A_{i, t-1}}+\beta_{2} \frac{S A L E S_{i, t}}{A_{i, t-1}}+\beta_{3} \frac{\Delta \text { SALES }_{i, t}}{A_{i, t-1}}+\varepsilon_{i, t}
$$

Where: $C F O_{\mathrm{i}, \mathrm{t}}$ : operating cash flow on the cash flow statement of company $i$ in period $t ; A_{i, t-1}$ : Total assets of company $i$ in the previous year; Sales $_{\mathrm{i}, \mathrm{t}}$ : Revenue of company $\mathrm{i}$ for the current year; $\Delta$ Sales $_{\mathrm{i}, \mathrm{t}}$ : The difference in the company's revenue for the current year and the previous year; $\varepsilon_{\mathrm{i}, \mathrm{t}}:$ the rest is unexplained from the equation; $\beta_{1}, \beta_{2}, \beta_{3}$, are the beta coefficients of the independent variables of the equation.

$$
\begin{aligned}
\frac{\operatorname{PROD}_{i, t}}{A_{i, t-1}}=\beta_{1} & \frac{1}{A_{i, t-1}}+\beta_{2} \frac{\operatorname{SALES}_{i, t}}{A_{i, t-1}}+\beta_{3} \frac{\Delta \text { SALES }_{i, t}}{A_{i, t-1}} \\
& +\beta_{4} \frac{\Delta \operatorname{SALES}_{i, t-1}}{A_{i, t-1}}+\varepsilon_{i, t}
\end{aligned}
$$

Where: $P R O D_{i, t}$ : Total value of cost of goods sold of company $i$ in the current year; $\Delta$ Sales $_{\mathrm{i}, \mathrm{t}-1}$ : difference between the sales of the previous year and year $\mathrm{t}-2 ; \varepsilon_{\mathrm{i}, \mathrm{t}}$ a residual term of firm $\mathrm{i}$ in current year; $\beta_{1}, \beta_{2}, \beta_{3}, \beta_{4}$ are the beta coefficient.

$$
\frac{\operatorname{DISCEXP}_{i, t}}{A_{i, t-1}}=\beta_{1} \frac{1}{A_{i, t-1}}+\beta_{2} \frac{\operatorname{SALES}_{i, t-1}}{A_{i, t-1}}+\varepsilon_{i, t}
$$


Where: DISEXP $P_{\mathrm{i}, \mathrm{t}}$ : includes Selling, Administrative and General Administration expenses of the company i for the current year $\varepsilon_{\mathrm{i}, \mathrm{t}}$ : a residual term; $\beta_{1}, \beta_{2}$, are the beta coefficient.

\section{Control Variables}

We incorporated in our investigations various controls variables that were assumed to simultaneously influence the connection between REM and cost of debt. For a firm risk's characteristic, we controlled for the volatility of firm size (SIZE), return on asset (ROA), the firm leverage and PPEFirm size (FS) was measured through the logarithm of the firm's total assets in the current year. $R O A$ is the net income divided by lagged total assets at year-end. Firm leverage ( $L E V)$, which is the total debt divided by total assets at the end of the fiscal year and $P P E$ is the net properties, plants and equipments/ total assets in the current year. We considered that the control variables SIZE, ROA had a negative influence on the cost of debt because when a company expands in size and uses assets effectively, it proves that the company has a good development, so the low risk leads to less use of capital outside the business (Kim et al., 2018). By contrast, LEV, PPE variables show a positive relation to cost of debt because of bad performance and high risk at firms.

\section{RESULTS AND DISCUSSION}

Table 1 illustrates the descriptive statistics of variables used in this study over the period 2010 to 2016. The mean values of firm size, ROA, leverage ratio and PPE were 27.3787, 0.0602, 0.5428, 0.2437 respectively. The standard deviation was quite low, which meant that the observations in the sample were distributed around the mean. Firm size had a value ranging from 23,5801 to 32,8265 , explicating that companies are diverse in size and outline overall representativeness, proportionally ROA ranked between 0.6455 and 0.7837 , the leverage ratio was from 0.0320 to 0.9481 and PPE was from 0.0002 to 0.9661 . The value of COD variables was from 0.0000 to 0.4997 while the min of REMCFO, REMPROD, REMEXP was below 0 . The highest value of them REMCFO, REMPROD, REMEXP were 53.1186; $10.8935 ; 6.9847$ respectively. 
Table 1: Descriptive Statistics of Variables

\begin{tabular}{lcccccccc}
\hline VARIABLE & COD & REMCFO & REMPROD & REMEXP & SIZE & ROA & LEV & PPE \\
\hline Mean & 0.0360 & -1.1032 & 0.9665 & -0.1276 & 27.3787 & 0.0602 & 0.5428 & 0.2437 \\
Std. Dev. & 0.0327 & 2.4980 & 1.1100 & 0.3393 & 1.5534 & 0.0663 & 0.2055 & 0.2015 \\
Min & 0.0000 & -15.2921 & -1.3454 & -2.4848 & 23.5801 & -0.6455 & 0.0320 & 0.0002 \\
Max & 0.4997 & 53.1186 & 10.8935 & 6.9847 & 32.8265 & 0.7837 & 0.9481 & 0.9661 \\
Obs & 1,687 & 1,687 & 1,687 & 1,687 & 1,687 & 1,687 & 1,687 & 1,687 \\
\hline
\end{tabular}

Table 2 presents the correlation matrix of the dependent and independent variables in the research model. The correlation coefficient between COD and three representative variables of REM including REMCFO, REMPROD, and REMEXP was a positive indication. The correlation rate between the three variables representing the highest REM expressed between REMCFO and REMEXP was 0.958 . This confirmed that the representative variables had a convergence in measurement for REM. In addition, the correlation coefficient between all the independent variables was smaller than the acceptable limit (0.8). As a result, having a multi collinearity phenomenon was difficult.

Table 2: Pearson correlation coefficient matrix

\begin{tabular}{lcccccccc}
\hline & COD & REMCFO & REMPROD & REMEXP & SIZE & ROA & LEV & PPE \\
\hline COD & 1 & & & & & & & \\
REMCFO & 0.004 & 1 & & & & & & \\
REMPROD & 0.042 & -0.1 & 1 & & & & & \\
REMEXP & 0.0084 & 0.958 & 0.0413 & 1 & & & & \\
SIZE & -0.0893 & 0.5707 & -0.2327 & 0.5469 & 1 & & & \\
ROA & -0.1768 & -0.0615 & 0.0895 & -0.0458 & -0.0309 & 1 & & \\
LEV & 0.0572 & 0.233 & 0.0081 & 0.2283 & 0.2896 & -0.5032 & 1 & \\
PPE & 0.2208 & -0.0028 & -0.0315 & 0.0016 & 0.1509 & -0.017 & -0.017 & 1 \\
\hline
\end{tabular}


Table 3: Dynamic GMM - Regression Results

\begin{tabular}{lcccccc}
\multirow{2}{*}{ Variables } & \multicolumn{2}{c}{ REMCFO } & \multicolumn{2}{c}{ REMPROD } & \multicolumn{2}{c}{ REMEXP } \\
\cline { 2 - 7 } & Coefficient & P-Value & Coefficient & P-Value & Coefficient & P-Value \\
\hline Lag of Dep. Var & $0.5974^{* * *}$ & 0.000 & $0.435^{* * *}$ & 0.000 & $0.5624^{* * *}$ & 0.000 \\
REMCFO & $0.0042^{* *}$ & 0.000 & & & & \\
REMPROD & & & $0.0035^{*}$ & 0.076 & & \\
REMEXP & & & & & $0.0295^{* * *}$ & 0.000 \\
SIZE & $-0.0062^{* * *}$ & 0.000 & -0.0003 & 0.876 & $-0.0039^{* * *}$ & 0.000 \\
ROA & $-0.0518^{* * *}$ & 0.000 & $-0.1163^{* *}$ & 0.034 & $-0.045^{* * *}$ & 0.000 \\
LEV & $0.040^{* * *}$ & 0.000 & -0.0211 & 0.585 & -0.001 & 0.767 \\
PPE & $0.0306^{* * *}$ & 0.000 & $0.0234^{* * *}$ & 0.001 & $0.027^{* * *}$ & 0.000 \\
CONSTANT & $0.1636^{* * *}$ & 0.000 & 0.0362 & 0.274 & $0.1074^{* * *}$ & 0.000 \\
\hline AR (1) & 0.015 & 0.047 & 0.019 \\
\hline AR (2) & 0.304 & 0.258 & 0.348 & \\
\hline Hansen test & 0.285 & 0.119 & 0.336 & \\
\hline
\end{tabular}

*, **, *** denotes the level of significance of $10 \% ; 5 \%$ and $1 \%$ respectively;

The Coefficient of REMCFO, REMPROD, REMEXP were 0.0042 (level of significance of 5\%), 0.0035 (level of significance of 10\%), 0.0295 (level of significance of $1 \%$ ) respectively. The estimation of model displayed that real activities earnings management had a positive impact on cost of debt with a statistically significant coefficient. This conclusion confirmed the positive association between REM and the cost of debt for Vietnamese listed companies, and supports our first hypothesis and was compatible with the results of preceding studies (Bharath et al., 2008; Francis et al., 2005).

Overall, the result suggested that the higher REM led to a higher cost of debts in listed firms in Vietnam. The greater information asymmetry because of an undeveloped debt market, the lack of transparency and enforcement of regulations, weak supervision, weak credit analysis and poor risk management could make it easier for managers to manipulate earnings. The results showed REM's a negative impact on a company's development in the long term. A company's image, reputation and operating results are affected by earnings manipulation of the manager. Manipulation activities 
result in a company's cash flow being negatively affected and leads to companies needing to use external capital at a higher cost of capital.

This empirical evidence also supports out prediction that the cost of debt in Vietnamese listed companies is positively related to LEV and PPE since those variables referred to high risks, but are negatively related to firm size and ROA due to good performance and security. For a company with a large leverage ratio, it will lead to liquidity risk and difficult to handle off due debts if it does not generate appropriate revenue. Therefore, the cost of debt will increase for these cases. Firms with a large PPE should consider other factors of resource efficiency in generating corresponding revenue.

\section{CONCLUSION}

Previous research have described that managers want to undertake economic adjustments that can have long-term outcomes for manipulating earnings. Nevertheless, there has not been a systematic research examining the economic consequences of real activities earnings management in the Vietnam stock market. This study investigated the association between REM and the cost of debt for Vietnamese listed companies. It was expected that the association between REM and cost of debt was positive because higher risks require higher returns. The regression result indicated the same correlation that REM has a positive relationship with COD as in many previous research such as Aldamen and Duncan (2013); Bharath et al. (2008); Francis et al. (2005) and Gray et al. (2009).

Our study provides vital implications for investors, managers, regulators, and researchers. The results can help stakeholders to understand more about the possibility of the negative effect of REM on future cash flow and the invisibility, and the inherent risks of REM. Therefore, investors should price the cost of debt and compensate for those risks; managers should consider what they should do to decrease the cost of debt. Regulators, who are concerned with quality of financial statements should wonder how to detect, penalize and prevent earning managements in general and REM in particular. In addition, other researchers should gain insights into this field in the future. 
There are several limitations in this study, which provides new possible avenue for future research. The first restriction is that we only focussed on REM and cost of debt, so the next research could extend to other earnings management methods like earnings persistence and cost of capital. Secondly, the sample was limited to Vietnam, therefore prospective research could investigate REM practices in businesses in emerging markets. This research examined whether the association between real earnings management and the cost of debt is influenced by a firm's level of debt. In future research, bank debts and earnings persistence could be good choices as control variables.

In spite of those restrictions, this study provides readers who are policy-makers, regulators, domestic as well as foreign investors, financial institutions, business organizations the literature on earnings management and relevant implications in the context of emerging markets like Vietnam.

\section{ACKNOWLEDGEMENTS}

This research is funded by University of Economics and Law, Vietnam National University Ho Chi Minh City, Vietnam.

\section{REFERENCES}

Aldamen, H., \& Duncan, K. (2013). Pricing of innate and discretionary accruals in Australian debt. Accounting \& Finance, 53(1), 31-53.

Arellano, M., \& Bond, S. (1991). Some tests of specification for panel data: Monte Carlo evidence and an application to employment equations. The Review of Economic Studies, 58(2), 277-297.

Balvers, S. (2009). Earnings management and the cost of capital (Master thesis, Erasmus University Rotterdam, Rotterdam, Netherlands).

Bharath, S. T., Sunder, J., \& Sunder, S. V. (2008). Accounting quality and debt contracting. The Accounting Review, 83(1), 1-28. 
Chen, H., Chen, J. Z., Lobo, G. J., \& Wang, Y. (2010). Association between borrower and lender state ownership and accounting conservatism. Journal of Accounting Research, 48(5), 973-1014.

Cohen, D. A., \& Zarowin, P. (2010). Accrual-based and real earnings management activities around seasoned equity offerings. Journal of Accounting and Economics, 50(1), 2-19.

El Diri, M. (2018). Definitions, activities, and measurement of earnings management. In Introduction to earnings management (pp. 5-44). Springer, Cham.

Firth, M., Mo, P. L., \& Wong, R. M. (2012). Auditors' organizational form, legal liability, and reporting conservatism: Evidence from China. Contemporary Accounting Research, 29(1), 57-93.

Francis, J., LaFond, R., Olsson, P., \& Schipper, K. (2005). The market pricing of accruals quality. Journal of Accounting and Economics, 39(2), 295-327.

Gelb, D. S., \& Zarowin, P. (2002). Corporate disclosure policy and the informativeness of stock prices. Review of Accounting Studies, 7(1), $33-52$.

Goldman, E., \& Slezak, S. L. (2006). An equilibrium model of incentive contracts in the presence of information manipulation. Journal of Financial Economics, 80(3), 603-626.

Graham, J. R., Harvey, C. R., \& Rajgopal, S. (2005). The economic implications of corporate financial reporting. Journal of Accounting and Economics, 40(1-3), 3-73.

Gray, P., Koh, P. S., \& Tong, Y. H. (2009). Accruals quality, information risk and cost of capital: Evidence from Australia. Journal of Business Finance \& Accounting, 36(1-2), 51-72.

Hadani, M., Goranova, M., \& Khan, R. (2011). Institutional investors, shareholder activism, and earnings management. Journal of Business Research, 64(12), 1352-1360. 
Healy, P. M., \& Wahlen, J. M. (1999). A review of the earnings management literature and its implications for standard setting. Accounting Horizons, 13(4), 365-383.

Hu, J., Weng, Y.-C., \& Wang, F. (2020). The effect of the internal control regulation on reporting quality in China. Borsa Istanbul Review. Forthcoming.

Jensen, M. C., \& Meckling, W. H. (1976). Theory of the firm: Managerial behavior, agency costs and ownership structure. Journal of Financial Economics, 3(4), 305-360.

Karjalainen, J. (2011). Audit quality and cost of debt capital for private firms: Evidence from Finland. International Journal of Auditing, 15(1), 88-108.

Kim, J. H., Lee, S. H., \& Keun Yoo, Y. (2018). Real earnings management and the cost of debt capital: International evidence. Asia-Pacific Journal of Accounting \& Economics, 1-22.

Kim, J.-B., \& Sohn, B. C. (2013). Real earnings management and cost of capital. Journal of Accounting and Public Policy, 32(6), 518-543.

Kothari, S. P., Mizik, N., \& Roychowdhury, S. (2015). Managing for the moment: The role of earnings management via real activities versus accruals in SEO valuation. The Accounting Review, 91(2), 559-586.

Laux, C., \& Laux, V. (2009). Board committees, CEO compensation, and earnings management. The Accounting Review, 84(3), 869-891.

Lim, Y. (2011). Tax avoidance, cost of debt and shareholder activism: Evidence from Korea. Journal of Banking \& Finance, 35(2), 456-470.

Lorca, C., Sánchez-Ballesta, J. P., \& García-Meca, E. (2011). Board effectiveness and cost of debt. Journal of Business Ethics, 100(4), 613-631. 
Phillips, J. D., Pincus, M., Rego, S. O., \& Wan, H. (2004). Decomposing changes in deferred tax assets and liabilities to isolate earnings management activities. Journal of the American Taxation Association, 26(s-1), 43-66.

Pittman, J. A., \& Fortin, S. (2004). Auditor choice and the cost of debt capital for newly public firms. Journal of Accounting and Economics, 37(1), 113-136.

Prevost, A. K., Rao, R. P., \& Skousen, C. J. (2008). Earnings management and the cost of debt. Available at SSRN 1083808.

Ronen, J., \& Yaari, V. (2008). Earnings management (Vol. 372): Springer.

Roychowdhury, S. (2006). Earnings management through real activities manipulation. Journal of Accounting and Economics, 42(3), 335-370.

Schipper, K. (1989). Earnings management. Accounting Horizons, 3(4), 91-102.

Walker, M. (2013). How far can we trust earnings numbers? What research tells us about earnings management. Accounting and Business Research, 43(4), 445-481.

Zang, A. Y. (2012). Evidence on the trade-off between real activities manipulation and accrual-based earnings management. The Accounting Review, 87(2), 675-703. 